\title{
Toepassing van 'n lineêre regressiemodel op verskillende inligtingstelselfasette
}

\author{
P.J.S. Bruwer \\ Bestuursinligtingstelsels, Nagraadse Skool vir Bestuurswese, PU vir CHO, Potchefstroom 2520, Republiek van Suid-Afrika
}

Ontvang 3 Maart 1990, aanvaar 4 Februarie 1991

\begin{abstract}
Application of a linear regression model to different information system facets Evaluation techniques with regard to the information system function in organizations could well be used to serve as a tool to identify problem areas and the corresponding corrective actions to be taken. In the past quite a number of computer-based application systems have failed in large as well as small organizations not bocause of inadequate technical quality but because some important non-technical factors of critical importance for the success of the system have not been diagnosed timely. In a previous research project (Bruwer: 1983) a restricted linear regression model method has been used to evaluate the success of the information system function in organizations. In this article the same model is applied on three different areas of the information system function. These areas are: Aspects of strategic planning of information systems; evaluation of the use of micro-computer systems and the evaluation of computer facilities in organizations.

Evalueringstegnieke met betrekking tot die werkverrigting van die inligtingstelselfunksie in organisasies kan in 'n groot mate 'n positiewe bydrae lewer tot die identifisering van knelpunte en tot die ooreenkomstige korrektiewe aksies wat geneem kan word. In die verlede het vele gerekenariseerde stelsels in groot sowel as klein organisasies misluk omdat sekere belangrike faktore wat bepalend vir die sukses daarvan was, maar nie noodwendig tegnies van aard was nie, nie betyds gediagnoseer kon word nie. In 'n vorige navorsingsprojek is 'n beperkte lineêre regressiemodel gebruik om die sukses van die inligtingstelselfunksie in organisasies te evalueer. In hierdie artikel word die model loegepas op drie verskillende areas van die inligtingstelselfunksie, naamlik vir strategiese beplanningsdoeleindes, die evaluering van mikrorekenaarstelsels en ook om rekenaarfasiliteite in organisasies te evalueer.
\end{abstract}

\section{Inleiding}

In 'n vorige navorsingsprojek (Bruwer, 1983) is 'n beperkte lineêre regressiemodel gebruik om die sukses van 'n inligtingstelsel in 'n organisasie te evalueer. Die filosofie en metodologie van dic model word volledig bespreek deur Bruwer en Hattingh (1985).

Rekenaartegnologic het die afgelope dekade eksponensieel gegroei in terme van gesofistikeerdheid - nie alleen ten opsigte van apparatuur en netwerke nie, maar ook met betrekking tot programmatuur beskikbaar op hoofraam sowel as mikrorekenaarstelsels. Bogenoemde model is in 'n navorsingsprojek gebruik waar drie verskillende areas in die inligtingstelselopset ondersoek en geëvalueer is. Die drie areas is die volgende:

1. Strategiese beplanning van inligtingstelsels in organisasies;

2. die evaluering van mikrorekenaarstelsels; en

3. die evaluering van rekenaarfasiliteite in organisasies.

In die volgende afdeling word die model vir strategiese beplanningsdoeleindes in 'n organisasie toegepas, terwyl dit in die daaropvolgende afdeling vir die evaluering van mikrorekenaarstelsels in klein ondernemings in Suid-Afrika toegepas word. Daarna word daar met behulp van die model ondersoek ingestel na rekenaarfasiliteite in organisasies en in die laaste afdeling word ' $n$ paar gevolgtrekkings en aanbevelings gemaak.

\section{Toepassing van die model vir strateglese beplan- ning van inligtingstelsels}

McLean en Soden (1977: 83) omskryf die volgende stappe in die strategiese beplanningsproses:

1. Die daarstel van 'n missie van die inligtingstelselfunksie.

2. 'n Omgewingsverkenning om die inligtingstelselgeleenthede, bedreiginge en risiko's te identifiseer.

3. Die daarstel van inligtingstelseldoelstellings wat die verlangde resultate van die inligtingstelsel definieer. Hierdie doelstelling moet so na moonulik verband hou met die strategiese doelstellings van die organisasie.

4. Die ontwikkeling van inligtingstelselstrategië, met ander woorde hoe die gestelde doelwitte bereik kan word.

5. Die definiëring van 'n inligtingstelselbeleid as riglyn om die strategie ten uitvoer te bring.

6. Die verwerking van hierdie doelstellings, strategiez en beleid in lang-, medium- en kortermynplanne.

7. Die implementering van die planne en meting van vordering met verloop van tyd.

Die hoofdoelstelling vir die toepassing van die model was om veral stap 2 aan te spreek, asook om 'n metode daar te stel waarvolgens die vordering van die inligtingstelselfunksie oor tyd gemonitor kan word, met ander woorde stap 7 in die beplanningsproses.

Vir die toepassing van die model vir strategiese beplanningsdoeleindes vir inligtingstelsels is daar ' $n$ vraelys ontwerp waarin 38 aspekte rakende die doeltreffende werkverrigting van die inligtingstelselfunksie vervat is. Hierdie aspekte is in die vraelys ingesluit nadat onlangse werk deur Alloway (1980), Bailey en Pearson (1983) Ives, Hamilton en Davies (1980), Rockart (1982) en Doyle en Miller (1984) deeglik bestudeer is.

Die vraelys is in vyf afdelings onderverdeel. Afdeling A het 34 aspekte van die inligtingstelselfunksie bevat waarvan die belangrikheid daarvan op 'n 7-puntskaal gezvalueer moes word. Afdeling B het toekomstige behoeftes vir inligtingstelsels aangespreek. Afdeling $C$ het dieselfde aspekte as Afdeling $A$ bevat behalwe dat in hierdie geval die werkverrigting van die aspekte binne die organisasie geèvalueer moes word. Afdeling $D$ het op sy beurn weer dieselfde aspekte as Afdeling $B$ bevat wat net soos Afdeling $C$ hanteer moes word. Die laaste afdeling het vrae omtrent demografiese data bevat asook 'n enkele vraag waar die sukses van 
die totale inligtingstelselfunksie geěvalueer moes word.

Die vraelys is uitgestuur na alle persone in middel- en hoëvlakbestuur van 'n baic groot organisasie in Suid-Afrika. 'n Totaal van 375 voltooide vraelyste is terugontvang wat 'n respons van $80 \%$ verteenwoordig het.

\section{Verwerking van data}

In die verwerking van die data is daar onder andere van die volgende tegnieke gebruik gemaak: Frekwensie, faktorontleding, stapgewyse lineêre regressie, meervoudige lineêre regressie en dan natuurlik die genoemde model (Bruwer \& Hattingh: 1985).

Lineêre regressiemetodes, tesame met die 34 aspekte as onafhanklike veranderlikes en die enkele vraag aangaande die sukses van die inligtingstelsels as afhanklike veranderlike, is cerstens gebruik.

Die eerste stap in die analise was 'n poging om die sukses van die inligtingstelsel deur middel van 'n geskikte deelversameling-veranderlikes te verklaar. Die kriterium wat in hierdie geval gebruik is, is die totale variansie van die afhanklike veranderlike as resultaat van 'n lineêre kombinasie van 'n gegewe versameling veranderlikes, ook bekend as die kwadreerde meervoudige korrelasie koëffisiënt $\left(R^{2}\right)$. Aangesien ' $n$ aantal veranderlikes in die versameling 'n verhoogde neiging van $R^{2}$ tot gevolg het, is die aangepaste $R^{2}\left(\mathrm{Ra}^{2}\right)$ wat die verskynsel in ag neem, as meer geskik beskou.

Die data van middelvlak- en hoëvlakbestuur is afsonderlik ontlced en die deelversamelings wat $\mathrm{Ra}^{2}$ in beide gevalle maksimiseer, is gekies as synde die onafhanklike verander-

Tabel 1 Suksesfaktore vir middel- en hoëvlakbestuur

Middelvlakbestuur
1. Beskikbaarheid en tydigheid
van verslae aan gebruikers.

van verslae aan gebruikers.

2. Volume van uitvoerinligting.

3. Kostetoedeling van IS-dienste na gebruikers.

4. IS-ondersteuning aan gebruikers in die voorbereiding van voorstelle vir nuwe stelsels.

5. Buigsasmheid van data en verslae. 5. Akkurantheid van uitvoerinligting.

(AKK)

6. Houdings van IS-personeel teenroor gebruikers.

7. Of gebruikers die stelsels verstaan.

8. Aanpasbaarheid van stelsels met betrekking tot veranderde gebruikersbehoeftes.

9. Topbestuur se betrokkenheid in definiëring van die IS-beleid. likes te wees wat die afhanklike veranderlike die beste verklaar.

\section{Suksesfaktore vir middel en hoevlakbestuur}

Die faktore wat die sukses van middel- en hoevlakbestuur onderskeidelik die beste verklaar, word in Tabel 1 weergegee.

Vir die doeleindes van die toepassing van die model is daar slegs van hoëvlakbestuur se data gebruik gemaak. Die volgende regressiemodel is gevind (let op dat die afkortings soos genoem in Tabel 1, gebruik word):

$$
\begin{aligned}
\text { SUKSES }= & 1,37+, 23(\text { KWALIT) }+, 36(\text { VOL })+.20 \text { (TYD) } \\
& -, 13(\text { AF })+.25(\text { AKK })+, 20(\text { SO })+, 14 \text { (SEKUR) }
\end{aligned}
$$

\section{Beperkte regressiemodel}

By verskillende vlakke van die veranderlike AF is minimum en maksimum vlakke van die afhanklike veranderlike SUKSES deur middel van lineêre programmeringstegnieke bepaal (Bruwer, 1983: 30). Kyk na Figuur 1.

Die waardes van die ander veranderlikes (beslissingsveranderlikes) word deur die model vir elke minimum en maksimum van SUKSES verskaf. Vir die spesifieke organisasie is die waarde van AF as 4,18 gemeet en dié van SUKSES as 4,39. Deur die model toe te pas met $A F=4,18$ kan SUKSES se maksimum waarde en die waarde van die ander beslissingsveranderlikes bereken word.

Die verskil tussen die gemete waardes van die veranderlikes en die optimale waardes het 'n prioriteitsvolgorde verskaf van die veranderlikes of faktore waaraan daar dringend aandag gegee moes word.

Hierdie metodologie kan dien as basis vir stappe 2 en 7 in die strategiese beplanningsproses, waardeur deeglike wetenskaplik gefundeerde interne evaluering van die inligtingstelselfunksie uitgevoer kan word, en dieselfde instrument gebruik kan word om vordering oor tyd te monitor.

\section{Toepassing van die model in die evaluering van mikrorekenaarstelsels}

Die ondersoek is uitgevoer in die kleinsakesektor van SuidAfrika. Nadat 'n voorondersoek in $\mathbf{3 0}$ kleinsakeondernemings, met behulp van vraelyste uitgevoer is, is 'n vraelys

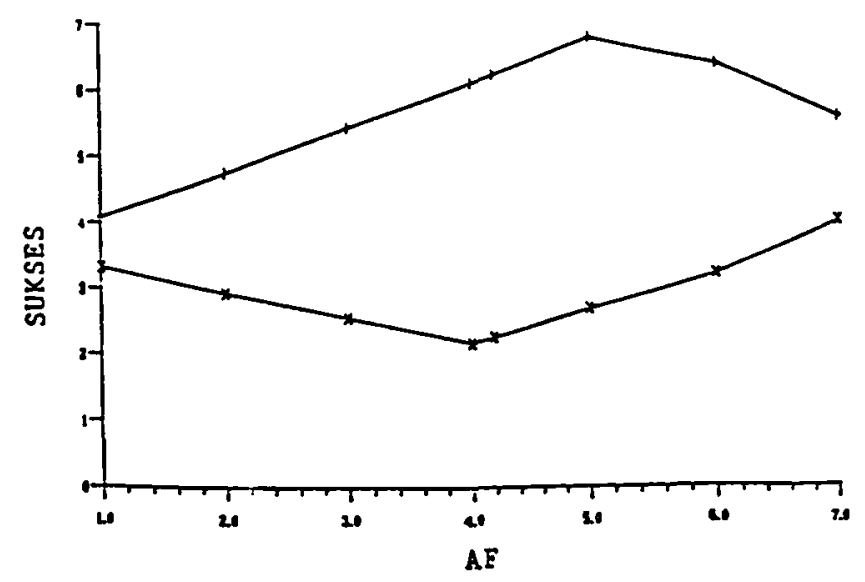

Figuur 1 Optimale waardes van sukses by verskillende vlakke van AF 
ontwerp wat 'n deelversameling was van die vrae wat in die voorondersoek gebruik is. 'n Paar feitelike vrae en 'n aantal houdingsvrae wat op 'n 7-puntskaal beantwoord moes word, is in dié vraelys ingesluit.

'n Adreslys en etikette van 'n ewekansige steekproef van 5000 kleinsakeondememings in Suid-Afrika is vanaf die Buro vir Marknavorsing, Universiteit van Suid-Afrika in Pretoria verkry. Om ' $n$ idee te probeer verkry omtrent die persentasie kleinsakeondernemings wat reeds van mikrorekenaars gebruik maak, is daar vervolgens 'n ewekansige steekproef van 500 uit die 5000 adresse getrek en in vraelys met net 'n enkele vraag, naamlik of die onderneming van 'n mikrorekenaarstelsel gebruik maak of nie, is uitgestuur.

Uit die respons op die vraelys het geblyk dat $18,5 \%$ van die ondememings wel mikrorekenaars gebruik. Omdat die waarskynlikheid groot is dat 'n groot persentasie nierespondente nie oor mikrorekenaars beskik nie, is hierdie syfer as 'n oorskatting van mikrorekenaargebruik in SuidAfrika gesien. In 'n poging om te verseker dat genoeg vraelyste terugontvang sou word sodat sinvolle verwerking gedoen kan word, is vraelyste na al die oorblywende 4500 adresse uitgestuur.

Die respons in hierdie geval was $23,3 \%$ waarvan $14,6 \%$ van die respondente wel van mikrorekenaars gebruik maak.

\section{Toepassing van die model}

Net soos met dic strategiese beplanningsprojek, is daar van lineêre regressiemetodes gebruik gemaak om te bepaal watter faktore die welslae van die mikrorekenaarstelsels die beste verklaar.

Uit 'n metingsoogpunt was die aantreklikste metode om die welslae te meet, die tevredenheid van die bestuurder met sy mikrorekenaarstelsel. 'n 7-Puntskaal is gebruik vir die meting daarvan.

Die deelversameling van veranderlikes wat $53 \%$ van die variansie van die suksesveranderlike verklaar het $\left(\mathbf{R a}^{2}=\right.$ ,53), is die volgende:

1. Dic hoofrede vir die aankoop van die rekenaar.

2. Tipe probleme wat ondervind is.

3. Hoogste vlak van rckenaaropleiding.

4. Mate waartoe die stelsel tot administratiewe werksvermindering bygedra het.

5. Tot welke mate die rekenaarstelsel aan die agent se voorstelling daarvan voldoen.

6. Tot welke mate dic uitvoer van die rekenaar vir besluitnemingsdoeleindes aangewend word.

Weereens is die model (Bruwer, 1983: 3) toegepas op hierdie veranderlikes en net soos in die vorige afdeling was dit moontlik om die prioriteitslys saam te stel deur middel van die lineêre programmeringstegnieke in die model.

\section{Toepassing van die model by die evaluering van rekenaarfasiliteite in organisasies}

Die derde toepassing van die model was om rekenaarfasiliteite in organisasies te evalucer. In hierdie geval is as teikengroep alle Suid-Afrikaanse Universiteite gebruik.

'n Vraelys van redelik wye omvang, waarin 70 aspekte in drie afdelings gedek word, is ontwerp. In Afdeling $A$ is daar gekonsentreer op vrae rondom rekenaarondersteuning ten opsigte van opleiding en navorsing. In die tweede plek het die vrae in hierdie afdeling ook gehandel oor administratiewe ondersteuning.

Alle vrae moes op 'n 7-puntskaal beantwoord word. In Afdeling B het die vrae gehandel oor algemene inligting aangaande rekenaardienste by die universiteite. Die laaste afdeling het evalueringsvrae bevat waarvan drie kopiez deur drie verskillende respondente van elke universiteit voltooi moes word. Die vraelys is uitgestuur na 18 universiteite.

\section{Toepassing van die model}

Dit het 'n redelike tyd geneem voordat respons van die universiteite ontvang is. Elf van die 18 universiteite het gereageer en heelwat later nog twee sodat 'n total van 13 uit 18 terugontvang is.

Die lineêre regressiemodel is toegepas deur van die laaste afdeling se data gebruik te maak. Daar is besluit on die algehele sukses van Rekenaardienste by 'n universiteit te bestudeer (afhanklike veranderlike).

Die veranderlike is geêvalueer in 'n vraag in die vraelys en ons noem hom SUKSES. Behalwe daarvoor, is aanvaar dat (vir die doel van hierdie ondersoek) die volgende veranderlikes (onafhanklike veranderlikes) 'n beduidende invloed op die SUKSES kan hê:

- Die tevredenheid met die wyse waarop begrotingsperspektiewe deurgegee word (aangedui as TEVREDE).

- Die beskikbaarheid van bronne aan 'n universiteit (aangedui as HULPBRONNE).

- Die vermoè van universiteite om kundige personeel te bekom en te behou (aangedui as KUNDIG).

- 'n Behoorlike beleid aangaande die ontplooiing van rekenaarfasiliteite (aangedui as BELEID).

- Die mate van welslae om ondersteuning van sleutelpersone aan die universiteit te verkry (aangedui as ONDERSTEUNING).

- Die mate waartoe 'n universiteit se rekenaardiensteafdeling daarin slaag om rekenaartegnologie oor te dra aan die gemeenskap deur onder andere opleiding te verskaf (aangedui as OPLEIDING).

Deur regressiemetodes te gebruik is gevind dat die volgende onafhanklike veranderlikes die SUKSES die beste verklaar:

- TEVREDE

- HULPBRONNE

- BELEID

- ONDERSTEUNING

Die verkrege regressievergelyking is die volgende:

$\begin{aligned} \text { SUKSES }= & 2,19(\text { TEVREDE })+0,19 \text { (HULPBRONNE) } \\ & +, 26(\text { BELEID })+0,13(\text { ONDERSTEUNING })\end{aligned}$

\section{Beperkte lineêre regressiemodel}

By verskillende vlakke van die veranderlike HULP. BRONNE is die minima en maksima van SUKSES bepaal. Die optimalc waardes van SUKSES tesame met die optimale waardes van die veranderlikes TEVREDE, BELEID EN ONDERSTEUNING word in Figuur 2 gegee.

Uit die resultate is dit duidelik dat:

- Oor die algemeen groter SUKSES behaal word vir hoér vlakke van HULPBRONNE. 
- Die universiteite (wat betrek is in die ondersoek) oor die algemeen gemiddelde of bo-gemiddelde SUKSES behaal (4 of hoèr op die 7-puntskaal).

- Sommige universiteite beduidend beter vaar as by 'n gegewe vlak van HULPBRONNE omdat hulle 'n gesonde BELEID en goeie ONDERSTEUNING van sleutelpersone geniet.

\section{Gevolgtrekkings}

In hierdie projek waar daar verskillende fasette van die totale inligtinstelselfunksie deur die beperkte lineêre regressiemodel geexvalueer is, is dit duidelik dat die bruikbaarheid en toepassingsgebied van die model baie wyd is en groot potensiaal inhou.

In die cerste geval, naamlik die toepassing daarvan vir strategiese beplanningsdoeleindes, dien die model as instrument om ' $n$ basis vir die topbestuur van 'n organisasie te gee vanwaar verdere stappe in die strategiese beplanningsproses uitgevoer kan word. Die model kan ook in hierdie geval handig gebruik word om die inligtingstelselfunksie in organisasies te monitor.

In die geval van die gebruik van die model om die gebruik van mikrorekenaarstelsels in kleinsakeondememings te evalueer kon daar baie maklik aangetoon word (in prioriteitsvolgorde) watter faktore die grootste bydrae tot die welslae van die mikrorekenaarstelsel lewer.

In die laaste toepassing van die model in die evaluering van rekenaarfasiliteite aan Suid-Afrikaanse universiteite was dit duidelik dat 'n gesonde beleid omtrent die ontplooiing van rekenaarfasiliteite en die ondersteuning van sleutelpersone baie belangrik blyk te wees vir die algehele sukses van die inligtingstelselfunksie.

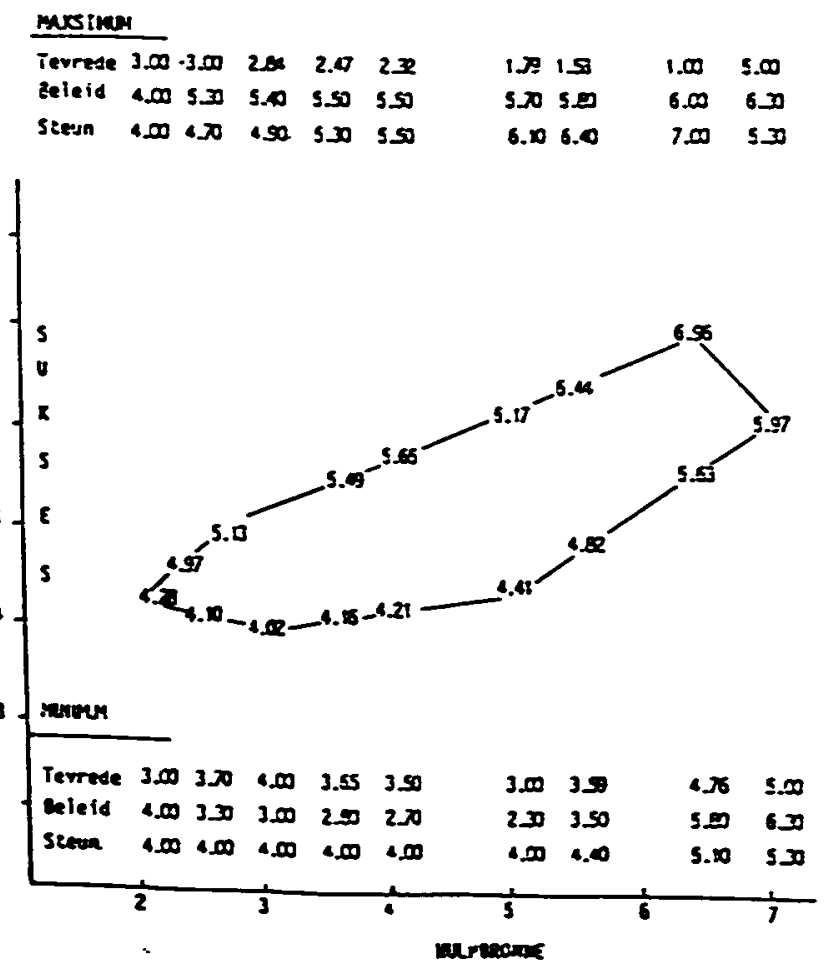

Figur 2 Optimale waardes van sukses en die beslissingsveranderlikes
Die model behoort met groot vrug ook toegepas te kan word in velde soos byvoorbeeld bemarking, finansiële bestuur, beleggingsanalises, ens.

\section{Summary}

In a previous research project (Bruwer: 1983) a restricted linear regression model method has been used to evaluate the success of the information system function in organizations.

In this project the same model is applied on three different areas of the information system function. These areas are:

- aspects of strategic planning of information systems;

- evaluation of the use of micro-computer systems; and

- the evaluation of computer facilities in organizations.

\section{Aspects of strategic planning of information systems}

According to McLean and Soden (1977: 83) the process of strategic planning for information systems involve seven steps. The second step being the scanning of the IS environment for opportunities, risks and threats.

The main goal of the application of the model was to address this step in the planning process as well as to provide a tool to monitor the IS function over time (step 7 in the planning process).

A questionnaire was developed and data collected from middle and higher level management of a large organization in South Africa. With the aid of the model success factors from higher level managements' viewpoint as well as success factors from middle level managements viewpoin could be determined.

\section{Evaluation of the use of micro-computer systems}

This project was launched in the small business sector in South Africa. Again a questionnaire was developed and a sample of 5000 small businesses in South Africa used to collect data on the use of micro-computer systems.

A response of $23 \%$ was received and the model were used to detcrmine key problem areas in the use of micro computers in small businesses.

\section{Evaluation of computer facilities in organizations}

The target group in this project were all South African universities. A questionnaire was developed and sent to 18 universities of which 13 responded. The model was then applied to determine factors influencing the quality of computer facilities of universities.

The successfull application of the model in these three information system areas shows the possibility of applying the model in other areas such as marketing and financial management.

\section{Verrysings}

Alloway, R.M. 1980. User manager's systems needs. CISR working paper no. 56. (Sloan School of Management, MIT). May.

Bailey, J.E. \& Pearson, S.W. 1983. A tool for computer user satisfaction. Management Science, Vol. 29, No. 5, 530-545, May. 
Bruwer, P.J.S. 1983. Evaluating the performance of computerbased information systems using a restricted linear regression model. Quaestiones Informaticas, Vol. 2, No. 3, 1-6 September.

Bruwer, P.J.S. \& Hattingh, J.M. 1985. Constrained regression models for optimization and forecasting. Orion, Vol. 1, No. 1 , 2-15.

Doyle, B.A. \& Muller, J. 1984. Measuring the effectiveness of computer-based information systems in the financial services sector. Working paper no. 84-1. Cape Town: Graduate School of Business. University of Cape Town.

Ives, B., Hamilion, B. \& Davis, G.B. 1980. A framework for research in computer-based management information systems. Management Science, Vol. 26, No. 9.

Martin, E.W. 1982. Critical success fuctors of MIS/DP executives. MIS Quarterly, Vol. 6, No. 2, 28-39. June.

McLean, E.R. \& Soden, J.V. 1977. Strategic planning for MIS. New York: Wiley-Interscience. 